\title{
Parity-related Changes in Body Weight May Influence the Zinc and Copper Status of Urban Pregnant Women: A Report from South Eastern Nigeria
}

\author{
Uchenna Ifeanyi Nwagha, Eghosa Edorisiagbon lyare', Sylvester Ogbonna Ogbodo², Polycarp Uchenna Agu, Titilope Helen \\ Olubobokun ${ }^{3}$, Paul Olisaemeka Ezeonu ${ }^{4}$, Azubuike Kanayo Onyebuchi ${ }^{4}$ \\ Departments of Physiology, Obstetrics and Gynaecology, 'Physiology, College of Medicine, University of Nigeria, Enugu Campus, Nsukka, \\ ${ }^{2}$ Gold Life Medical Laboratories, Enugu, ${ }^{3}$ Department of Physiology, Faculty of Basic Medical Sciences, University of Uyo, ${ }^{4}$ Department of \\ Obstetrics and Gynecology, Federal Teaching Hospital Abakalilki, Ebonyi State, Nigeria
}

\section{A B S T R A C T}

Background: Micronutrient replacement is done indiscriminately, without recourse to peculiar socioeconomic and sociodemographic variables. Particularly, the relationship between parity, body weight, and some micronutrients has received minimal attention in Nigeria. Aim: To determine the relationship between parity, body weight, and some micronutrients during pregnancy. Subjects and Methods: This is a cross-sectional study involving 130 pregnant women and 30 nonpregnant control. They were recruited from two health care facilities in Nigeria and grouped into nulliparous and multiparous. After a 24-h dietary recall, the weight $(\mathrm{W})$ and height $(\mathrm{H})$ were measured. The body mass index $(\mathrm{BMI})\left(\mathrm{W}\right.$ in $\mathrm{kg} / \mathrm{H}$ in $\left.\mathrm{m}^{2}\right)$ was calculated. Serum copper and zinc were estimated using flame atomic absorption spectrophotometer. Results: Multiparous nonpregnant subjects parity=3.0 (0.58) had higher weight $(P=0.037)$ and $B M I(P=0.035)$ than their nulliparous counterparts (parity=0). In addition, there were no significant difference in $\mathrm{Cu}$ and zinc levels between the two groups $(P=0.243$ and 0.402 , respectively). Expectedly, weight and BMI increased as pregnancy progressed. There was no significant difference in Cu levels between the three trimesters in the nulliparous pregnant and multiparous pregnant subjects. In the pregnant nulliparous subjects, the $\mathrm{Zn}$ levels of the $2^{\text {nd }}$ and $3^{\text {rd }}$ trimesters were significantly lower than that of the nonpregnant nulliparous subjects $(P<0.001$ and 0.039 , respectively). However, in multiparous pregnant subjects, only the $3^{\text {rd }}$ trimester Zn level was significantly lower than that of the nonpregnant controls $(P=0.017)$. Conclusion: Pregnancy weight gain is more pronounced in multiparous than nulliparous women. This parity-related pattern only affects the serum zinc levels, a situation that should be taken into consideration when formulating policies for nutritional replacement.

KEY WORDS: Africa, body mass index, copper, parity, pregnancy, zinc

\section{INTRODUCTION}

Body mass index (BMI) is a universally accepted indicator representing obesity by measuring weight in kilograms and dividing by height in meter square..$^{[1]}$ It has been classified that the BMI for normal weight in adults is $18.5-24.9 \mathrm{~kg} / \mathrm{m}^{2}$; underweight is less than $18.5 \mathrm{~kg} / \mathrm{m}^{2}$; overweight is $25.0-29.9 \mathrm{~kg} / \mathrm{m}^{2}$, while obese is greater than 30.0 $\mathrm{kg} / \mathrm{m}^{2}{ }^{\left[{ }^{2]}\right.}$ Obesity has been classified as a modern epidemic. It has been described as the fastest growing health problem in the United State of America, where approximately one-third of all US women are obese. ${ }^{[3]}$ Several criteria have been used to

\begin{tabular}{|l|l|}
\hline \multicolumn{2}{|c|}{ Access this article online } \\
\hline Quick Response Code & Website: \\
\hline & www.jbcrs.org \\
\cline { 2 - 2 } & \\
\hline
\end{tabular}

define obesity in pregnancy. These include; iincrease of $110 \%$ to $120 \%$ of ideal body weight, absolute weight of $>91 \mathrm{~kg}$ or BMI $>30 \mathrm{~kg} / \mathrm{m}^{2} .^{[4]}$ Overweight and obesity in pregnancy may be associated with some pregnancy-related complications. However, modification could be done to improve pregnancy outcome. Some of the complications include: birth defects, especially neural tube defects, ${ }^{[5,6]}$ complications during labor and delivery, ${ }^{[7]}$ fetal and neonatal death, ${ }^{[8]}$ hypertensive disorders in pregnancy, gestational diabetes, ${ }^{[9]}$ and delivery of large for gestational age infants..$^{[7,9]}$

It is beyond dispute that the regulation of body weight requires a balance between food intake and energy expenditure. Since the discovery of the adipocyte-derived hormone, leptin, in the early 1990s, ${ }^{\mid 10]}$ evidence has accumulated to support the existence of a physiological

Address for correspondence

Dr. Uchenna Nwagha,

Department of Physiology, Obstetrics and Gynecology, College of Medicine, University of Nigeria, Enugu Campus, Nsukka, Nigeria. E-mail: uchenna.nwagha@unn.edu.ng 
system that is responsible for the long-term regulation of food intake and energy balance. Leptin is a potent satiety factor $^{[11,12]}$ that circulates in plasma in proportion with body adiposity. ${ }^{[13]}$ Several workers have observed that the administration of leptin increases energy expenditure and decreases appetite ${ }^{[1,14-16]}$ through a decrease of the orexigenic neurotransmitters in hypothalamus. ${ }^{[16,17]}$ Leptin is essential for the establishment of pregnancy. ${ }^{[18]}$ It has also been reported that it is a fundamental fetal growth promoting factor ${ }^{[19,20]}$ independent of insulin-like growth-promoting factors) ${ }^{[21]}$ as reduced placental transport of leptin from mother to the fetus is associated with fetal growth retardation. ${ }^{[18]}$

Zinc $(\mathrm{Zn})$ plays a significant role in the regulation of the appetite. ${ }^{[22-24]} \mathrm{A}$ widely accepted mechanism for $\mathrm{Zn}$-induced regulation of appetite is changes in the metabolism of the hypothalamic neurotransmitters. ${ }^{[23,25]}$ The existence of a link between zinc-induced appetite regulation and leptin-induced appetite regulation was suggested by Mantzoros et al., ${ }^{[26]}$ and Mangian et al., ${ }^{[27]}$ when they observed that, in humans and rodents, zinc deficiency decreases, while $\mathrm{Zn}$ supplementation increases leptin levels. This suggests a positive correlation between leptin and $\mathrm{Zn}$ levels. ${ }^{[24]}$

Copper $(\mathrm{Cu})$ is a trace element that regulates the functions of several cuproenzymes that are essential for life ${ }^{[24]}$ and plays a significant role in antioxidant defense and immune development. ${ }^{[28]}$

$\mathrm{Zn}$ and $\mathrm{Cu}$ are beneficial during pregnancy. Both excesses and deficiencies have been reported to have profound and sometimes persistent effects on many fetal tissues and organs in the absence of clinical signs of deficiency in the mother. These effects have been reported to be through alterations in maternal and fetal metabolism; as a consequence of their essential role in enzymes and transcription factors and through their involvement in signal transduction pathways that regulate development. ${ }^{[29]}$

The relationship between body fat, BMI, leptin, and some micronutrients has received attention in some settings. The reports showed that plasma leptin level correlates positively with $\mathrm{BMI}^{13,24,30]}$ and plasma zinc level. ${ }^{[24]}$ Furthermore, $\mathrm{Cu}$ competes with $\mathrm{Zn}$ at absorptive sites, suggesting a role for $\mathrm{Cu}$ in the regulation of $\mathrm{Zn}$ level.

In Nigeria, despite the enormous resources from oil, poverty level remains remarkably high. Micronutrient supplementation is, therefore, routinely advocated. As a result, several micronutrient formulations (including copper and zinc) have flooded the Nigerian market with various unsubstantiated claims of superiority. It is exceedingly unfortunate, that these formulations were done without scientific evidence. Indeed, economic, geographical, sociocultural, and patient demographic peculiarities were not considered. Consequently, maternal mortality and morbidity has remained embarrassingly high, ${ }^{\mid 31]}$ and the attainment of the Millennium Development Goals is in doubt. Unfortunately, there is a dearth of information on the relationship between some micronutrients $(\mathrm{Cu}$ and $\mathrm{Zn)}$ status, parity, and obesity indices in pregnant and nonpregnant women. The present study was designed to investigate this in eastern Nigerian women and form the basis for more specific and detailed investigation.

\section{SUBJECTS AND METHODS}

\section{Study area}

The study was done in Enugu state in Southeast Nigeria between January and October 2009. The state is located in the hilly tropical rain forest about $230 \mathrm{~m}$ above sea level. The average annual temperature is between 23.1 and $31^{\circ} \mathrm{C}$ with a rainfall of $1520-2030 \mathrm{~mm}$. It has a mixed rural and urban population with the majority being Igbo's, with a projected population of 3.3 million out of which slightly more than $50 \%$ are females. Enugu state has a crude birth rate of 45 per 1000 , crude death rate of 18 per 1000 of the population, and a life expectancy of 51 years. ${ }^{\mid 32]}$ The maternal mortality rate ranges between 750 and 850 per 100,000 live births. ${ }^{[33,34]}$ Commonly eaten foods in Enugu include; rice, yam, cassava, beans, corn food, egusi, ogbono, orah, and vegetable soups.

\section{Study design and setting}

This is a cross-sectional study involving 130 normal pregnant women at various trimesters (34 in the first trimester, 44 in the second trimester, and 52 in the third trimester) attending antenatal clinic at University of Nigeria Teaching Hospital (UNTH) and Kenechukwu specialist hospital in Enugu. The control group consists of 30 nonpregnant women recruited from the staff of the above-named institutions. Subjects with febrile conditions, multiple pregnancy, preeclampsia, diabetes mellitus, and chronic renal disease, sickle cell anemia, and HIV infections were excluded from the study. Ethical approval was obtained from UNTH ethical review board. After obtaining informed written consent, the subjects that met the above criteria were recruited. Personal history, history of present pregnancy, obstetric history, medical history, family and social history, and review of systems were obtained. The gestational age was assessed from the last normal menstrual period. Trimester was defined as the first trimester $(<14$ weeks), second (14-27 weeks), and third ( $>27$ weeks). All the women were on routine iron and folic acid supplementation as recommended in Nigeria, but not on copper and zinc. The socioeconomic class was determined by the method 
of Szreter ${ }^{[35]}$ All the subjects belonged to the middle class. A 24-h dietary recall dialogue was conducted to estimate their dietary copper, zinc, and calorie intake. In this method, the subjects were required to recall the individual's exact food intake during the previous 24-h period or preceding day. Also, recorded were detailed descriptions of all foods and beverages consumed, including cooking methods and brand names (where possible). The amount of caloric, as well as copper and zinc contents, was estimated using the nutrient composition of commonly eaten staple foods in Nigeria, ${ }^{[36]}$ and other parts of the world. ${ }^{[37]}$

Medical and obstetric examinations were performed. The weight was measured to the nearest $0.1 \mathrm{~kg}$ using a standard weighing scale (Stadiometer, Seca, Model 220, and Germany). The height was measured with the same instrument, to the nearest $0.1 \mathrm{~cm}$, without shoes, with the feet together, standing as tall as possible with the eyes level and looking straight ahead. All subjects and controls were subjected to the same instrument and method of measurement.

BMI was calculated from the formula: Weight in $\mathrm{kg}$ divided by height in $\mathrm{m}^{2}$ (after converting the centimeter to meter and recorded as $\mathrm{kg} / \mathrm{m}^{2}$ ).

Estimation of copper and zinc; Five ( $5 \mathrm{~mL}$ ) of venous blood was collected from the antecubital vein from the subjects using sterile, disposable syringes. The samples were transferred into sterile, anticoagulant-free glass sample containers (plain tubes). Blood samples of the nonpregnant group were collected on the $5^{\text {th }}$ day of their menstrual cycle and analyzed after a negative pregnancy test. The blood samples were allowed to stand for about $30 \mathrm{~min}$ to clot and then centrifuged at 3,500 (rpm) for $15 \mathrm{~min}$. The serum was collected and kept frozen at $-20^{\circ} \mathrm{C}$ until analyzed. flame atomic absorption spectrophotometer (AAS); (Buck Scientific AAS/AES Model 205, United States of America) was used to assay the trace elements.

\section{Statistical analysis}

Statistical analysis was done using SPSS version 15.0 (Chicago, Illinois, USA) values were recorded as mean and standard deviation. The test for significance was done using student's $t$-test and one-way analysis of variance, followed by multiple comparisons using Tukey's honestly significant post hoc test.

\section{RESULTS}

\section{BMI and weight}

Results show that the mean (SD) BMI of the multiparous nonpregnant subjects (parity=3.0 (0.58) was significantly higher than that of the nulliparous nonpregnant subjects (parity=0) $P=0.035$ ) [Table 1]. The BMI for the nulliparous pregnant women was significantly different when compared with the nonpregnant nulliparous counterparts $(P<0.001)$. However, the nonpregnant versus $1^{\text {st }}$ trimester $(P=0.106)$ and the $1^{\text {st }}$ trimester versus $2^{\text {nd }}$ trimester, $(P=0.312)$ did not contribute to this change. This significant difference is mainly due to differences between the $2^{\text {nd }}$ and $3^{\text {rd }}$ trimesters. The BMIs of the $2^{\text {nd }}$ and $3^{\text {rd }}$ trimesters of the nulliparous pregnant subjects were significantly higher than that of the nulliparous nonpregnant subjects ( $P=0.014$ and $P=0.002$, respectively) [Table 2].

For the multiparous pregnant subjects, only the $3^{\text {rd }}$ trimester BMI was significantly higher than the nonpregnant multiparous $(P=0.032)$, whereas the BMI of the $1^{\text {st }}$ and $2^{\text {nd }}$ trimesters was not significantly different from that of the nonpregnant multiparous subjects $(P=0.463$ and $P=0.223$, respectively) [Table 3]. The changes in weight are also recorded in the tables.

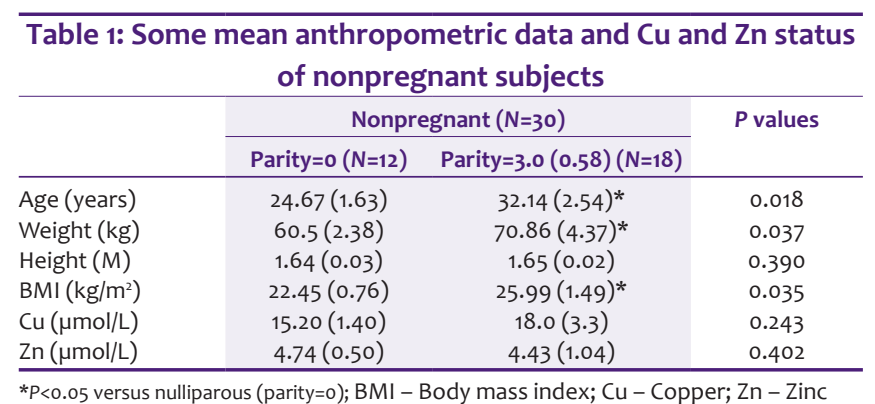

*P<0.05 versus nulliparous (parity=0); BMI - Body mass index; $\mathrm{Cu}$ - Copper; $\mathrm{Zn}-$ Zinc

Table 2: Some mean anthropometric data and $\mathrm{Cu}$ and $\mathrm{Zn}$ status of nulliparous pregnant and nonpregnant subjects

\begin{tabular}{|c|c|c|c|c|}
\hline & \multicolumn{4}{|c|}{ Nulliparous $(\mathrm{N}=66)$} \\
\hline & \multirow{2}{*}{$\begin{array}{l}\text { Nonpregnant } \\
\qquad(\mathrm{N}=12)\end{array}$} & \multicolumn{3}{|c|}{ Pregnant $(\mathrm{N}=54)$} \\
\hline & & $\begin{array}{c}1^{\text {st }} \text { trimester } \\
(\mathrm{N}=\mathbf{2 0})\end{array}$ & $\begin{array}{c}2^{\text {nd }} \text { trimester } \\
(\mathrm{N}=\mathbf{2 2})\end{array}$ & $\begin{array}{c}3^{\text {rd }} \text { trimester } \\
(\mathrm{N}=\mathbf{1 2})\end{array}$ \\
\hline Age (years) & $24.6(1.6)$ & $29.4(1.6)^{*}$ & $26.27(1.13)$ & $28.17(1.01)^{*}$ \\
\hline Weight (kg) & $60.5(2.4)$ & $71.9(5.1)$ & $69.82(4.31)$ & $79.17(3.19)^{\dagger}$ \\
\hline Height (M) & $1.6(0.03)$ & $1.68(0.02)$ & $1.61(0.02)$ & $1.64(0.03)$ \\
\hline $\mathrm{BMI}\left(\mathrm{kg} / \mathrm{m}^{2}\right)$ & $22.5(0.8)$ & $25.57(1.8)$ & $26.82(1.24)^{*}$ & $29.53(1.68) *$ \\
\hline $\mathrm{Cu} \mu \mathrm{mol} / \mathrm{L}$ & $15.20(1.40)$ & $15.9(1.6)$ & $14.6(2.3)$ & $18.6(4.1)$ \\
\hline $\mathrm{Zn} \mu \mathrm{mol} / \mathrm{L}$ & $4.74(0.50)$ & $4.32(0.46)$ & $2.64(0.26)^{*}$ & $3.31(0.53)^{*}$ \\
\hline
\end{tabular}

\begin{tabular}{|c|c|c|c|c|}
\hline & \multicolumn{4}{|c|}{ Multiparous parity=3.48 $(0.54)(\mathrm{N}=94)$} \\
\hline & \multirow{2}{*}{$\begin{array}{l}\text { Nonpregnant } \\
\qquad(N=18)\end{array}$} & \multicolumn{3}{|c|}{ Pregnant $(N=76)$} \\
\hline & & $\begin{array}{c}1^{\text {st }} \text { trimester } \\
(N=14)\end{array}$ & $\begin{array}{c}2^{\text {nd }} \text { trimester } \\
(\mathrm{N}=\mathbf{2 2})\end{array}$ & $\begin{array}{c}3^{\text {rd }} \text { trimester } \\
(\mathrm{N}=40)\end{array}$ \\
\hline Age (years) & $32.14(2.54)$ & $32.8(3.25)$ & $31.57(2.35)$ & $30.67(1.06)$ \\
\hline Weight (kg) & $70.86(4.37)$ & $65.6(5.31)$ & $72.0(6.9)$ & $83.07(3.07) *$ \\
\hline Height (M) & $1.65(0.02)$ & $1.59(0.05)$ & $1.60(0.03)$ & $1.67(0.01)$ \\
\hline BMI $\left(\mathrm{kg} / \mathrm{m}^{2}\right)$ & $25.99(1.49)$ & $25.76(1.75)$ & $27.90(1.89)$ & $29.96 \pm 1.19 *$ \\
\hline $\mathrm{Cu} \mu \mathrm{mol} / \mathrm{L}$ & $18.0(3.34)$ & $17.1(2.3)$ & $12.4(2.1)$ & $15.0 \pm(3.1)$ \\
\hline Zn $\mu \mathrm{mol} / \mathrm{L}$ & $4.43(1.04)$ & $4.27(0.66)$ & $2.76(0.28)$ & $2.67(0.24)^{*}$ \\
\hline
\end{tabular}




\section{Copper}

Although the serum copper levelwas higherin the multiparous nonpregnant subjects than the nulliparous nonpregnant subjects: 18.0 (3.3) versus $15.2(1.4) \mu \mathrm{mol} / \mathrm{L}$. The differences were not statistically significant $(P=0.243)$ [Table 1]. For the pregnant subjects, there was a tendency toward a peak at the $3^{\text {rd }}$ trimester for the nulliparous patients, while the peak occurred in the first trimester, and there after declined for the multiparous women. Again these differences were not significant $(P>0.05)$ [Tables 2 and 3].

\section{Zinc}

There was no significant difference between the $\mathrm{Zn}$ levels of the multiparous nonpregnant subjects and the nulliparous nonpregnant subjects $(P=0.402)$ [Table 1]. The $\mathrm{Zn}$ levels of the $2^{\text {nd }}$ and $3^{\text {rd }}$ trimesters of the pregnant nulliparous subjects were significantly lower than that of the nonpregnant nulliparous subjects $(P<0.001$ and $P=0.039$, respectively) [Table 2], whereas that of the $1^{\text {st }}$ trimester was not significantly different from that of the nonpregnant nulliparous subjects $(P=0.283)$. The $\mathrm{Zn}$ levels of the $1^{\text {st }}$ and $2^{\text {nd }}$ trimesters of the pregnant multiparous subjects were not significantly different from that of the nonpregnant multiparous subjects $(P=0.455$ and $P=0.074$, respectively) [Table 3]. Only the $Z n$ level of the $3^{\text {rd }}$ trimester multiparous pregnant subjects was significantly lower than that of the nonpregnant multiparous subjects $(P=0.017)$ [Table 3]. Table 4 shows the parity-related differences in copper and zinc levels between pregnant and nonpregnant women.

\section{DISCUSSION}

This study investigated the possible interrelationships between body weight, $\mathrm{Zn}$, and $\mathrm{Cu}$. Body weight has been reported to be positively correlated with serum leptin. ${ }^{[13,24,30]}$ Leptin and $\mathrm{Zn}$ are both involved in the physiological regulation of energy homeostasis. While leptin stimulates energy expenditure and inhibits appetite through altering hypothalamic neuropeptide concentrations, ${ }^{[13,16,17]}$ $\mathrm{Zn}$ stimulates appetite by altering the concentrations of neurotransmitters either in the circulation or locally in the hypothalamus. ${ }^{[38-40]}$

The interrelationship between leptin and $\mathrm{Zn}$ in humans has

\begin{tabular}{|c|c|c|c|c|c|c|}
\hline & \multicolumn{3}{|c|}{ Nulliparous women $(N=66)$} & \multicolumn{3}{|c|}{ Multiparous women (94) } \\
\hline & $\begin{array}{c}\text { Nonpregnant } \\
\quad(\mathrm{N}=12)\end{array}$ & $\begin{array}{l}\text { Pregnant } \\
(N=54)\end{array}$ & $P$ values & $\begin{array}{c}\text { Nonpregnant } \\
(\mathrm{N}=18)\end{array}$ & $\begin{array}{l}\text { Pregnant } \\
(\mathrm{N}=76)\end{array}$ & $P$ values \\
\hline $\mathrm{Cu} \mu \mathrm{mol} / \mathrm{L}$ & $15.20(1.40)^{\mathrm{a}}$ & $15.98(1.61)^{b}$ & 0.399 & $18.0(3.34)^{c}$ & $14.69(2.34)^{d}$ & 0.210 \\
\hline $\mathrm{Zn} \mu \mathrm{mol} / \mathrm{L}$ & $4.74(0.50)^{e}$ & $3.41(0.210)^{f}$ & $0.001^{\text {evsf }}$ & $4.43(1.04)^{g}$ & $2.99(0.20)^{\mathrm{h}}$ & $0.019^{\text {gvsh }}$ \\
\hline
\end{tabular}

been reported by Mantzoros et al., ${ }^{[26]}$ who observed that serum leptin concentration was significantly affected by Zn status. More specifically, some reports show that leptin levels decreased in response to $\mathrm{Zn}$ depletion and increased after $\mathrm{Zn}$ supplementation. Similar findings in rodents had earlier been reported. ${ }^{[27]}$ The mechanism by which $\mathrm{Zn}$ level affects leptin level is known to be through body fat and leptin synthesis. ${ }^{[41]}$ More recently, Ozdemir et al., ${ }^{[24]}$ reported a positive correlation between maternal serum leptin and maternal BMI and Zn levels. Furthermore, it has been observed that maternal $\mathrm{Zn}$, but not $\mathrm{Cu}$ level, affects maternal serum leptin level.

In the present study, a significantly increased BMI was observed in the multiparous nonpregnant subjects compared with the nulliparous nonpregnant subjects. According to $\mathrm{WHO}^{1}$ and $\mathrm{NIH}^{2}$ classification, the BMI for the nulliparous was normal, whereas the BMI for the multiparous showed that these subjects were overweight. This may suggest a parity-related predisposition to obesity. The effects of prepregnancy overweight and obesity on pregnancy outcome are well- documented. ${ }^{[6,42]}$ This has led to the clamor for women of child-bearing age and their healthcare providers to work together to assess and address the weight issue before, during and after pregnancy.

The copper level was biochemically higher, while the zinc level was lower (though statistically nonsignificant) in the multiparous than the nulliparous nonpregnant women. This observation was a bit surprising as a statistically significant parity-related increase in Zn status similar to BMI was expected, as BMI has been reported to be positively correlated with serum leptin $^{[13,24,30]}$ and leptin in turn has been reported to be positively correlated with Zn status. ${ }^{[24]}$ This may suggest that the relationship that exists between leptin and $\mathrm{Zn}$ may be lost in overweight and obese subjects, since it is well-established that these subjects are leptin resistant.

In this study, there was a progressive, parity-related increase in body weight and BMI as pregnancy progressed. This was expected because of the increasing growth of the fetus. In pregnancy, BMI is not valid for use in weight classification because the increased weight gain, which is expected in pregnancy, is due to the growth of the products of conception and not necessarily accumulation of fat. This means that the positive correlation between leptin and BMI may not exist in pregnancy.

The copper levels in the present study increased in the nulliparous but decreased in multiparous women as pregnancy progressed. Although these changes were not statistically significant, the biochemical difference is glaringly obvious. There have been reports of variations 
in copper levels during pregnancy. While some studies reported increasing levels as pregnancy progressed, ${ }^{[43-45]}$ others reported high prevalence of copper deficiency. ${ }^{[46,47]}$ However, these studies did not take parity into consideration while making such assumptions. Since micronutrient malnutrition is prevalent in the developing countries, ${ }^{[48]}$ the observed change in $\mathrm{Cu}$ level in the subjects in this study maybe a contributory factor in the physiological homeostatic mechanism protecting fetal growth.

In the multiparous and nulliparous pregnant women, zinc levels decreased as pregnancy progressed. Also noted was lower biochemical level of zinc in the multiparous pregnant group, though statistically nonsignificant. The decrease in the $\mathrm{Zn}$ status of the pregnant subjects in the $2^{\text {nd }}$ and $3^{\text {rd }}$ trimesters was not progressive. This was not surprising because $\mathrm{Zn}$ requirement increases during pregnancy mainly because of its utilization during embryogenesis and fetal development. ${ }^{[49]}$ This was similar to the observation of Hambidge et al., ${ }^{[50]}$ and Ejezie and Nwagha ${ }^{[51]}$ where a progressive decrease in $\mathrm{Zn}$ level during pregnancy was reported.

There is no doubt that obesity and overweight is highly prevalent in pregnancy in our environment. ${ }^{[52]}$ Indeed, there appeared to be a parity-related increase in body weight and $\mathrm{BMI}$ in nonpregnant and pregnant women. The parity-related changes in copper during pregnancy although statistical insignificant showed some biochemical relevance.

Routine supplementation during pregnancy has been the usual practice in Nigeria and indeed many developing countries. This has been indiscriminately undertaken without recourse to the peculiar micronutrient needs in a varied geographic and socioeconomic situation. Indeed it seems plausible, from this preliminary study that parity may influence maternal micronutrient composition. Consequently, it may not be totally absurd to advocate that parity be considered as a critical variable in the formulation of micronutrient replacement policies during pregnancy and lactation. The composition and quantity of micronutrient required during pregnancy should not be the same for all pregnant women. Body weight and parity should play a significant role in making the appropriate choices.

The cross-sectional and hospital-based nature of the study may have limitations over the findings. Again, the small sample size and the nonconsideration of age as a confounding variable may have affected the outcome. Indeed, it would have been more appropriate to use the Esha Pro software (ESHA Research, USA) to aid the assessment of total energy and micronutrient intake. Further studies, which must, be longitudinal, with higher sample size should be instituted to enable a clear understanding on the effect of parity on micronutrients stores. Indeed, studies should include serum leptin levels to determine its relationship with serum zinc, copper, and BMI.

The results of this study further highlight the importance of assessment of weight and micronutrient status before, during, and after pregnancy. This will enable the institution of the appropriate measures to ameliorate maternal micronutrient deficiency, avoid micronutrient overdose, and achieve optimal fetomaternal outcome.

\section{REFERENCES}

1. Gilmore J. Body mass index and health. Health Reports 1999;11:31-43.

2. World Health Organization. Obesity: preventing and managing the global epidemic. Report of a WHO consultation, WHO technical report series 894; 2000.

3. American Congress of Obstetricians and Gynecologists (ACOG). ACOG issues guidelines to ob-gyns on the impact of obesity during pregnancy. Available from: http://www.acog.org/from_home/ publications/press_releases/nr08-31-05-2.cfm 2005. [Last accessed on 2012 Mar 11].

4. Davies GA, Maxwell C, McLeod L, Gagnon R, Basso M, Bos H, et al. Obesity in Pregnancy. J Obstet Gynaecol Can 2010;32:165-73.

5. Watkins ML, Rasmussen SA, Honein MA, Botto LD, Moore CA. Maternal obesity and risk for birth defects. Pediatrics 2003;111:1152-8.

6. Oddy WH, De Klerk NH, Miller M, Payne J, Bower C. Association of maternal prepregnancy weight with birth defects: Evidence from a case-control study in Western Australia. Aust N Z J Obstet Gynaecol 2009;49:11-5.

7. Cedergren MI. Maternal morbid obesity and the risk of adverse pregnancy outcome. Obstet Gynecol 2004;103:219-24.

8. Cnattingius S, Bergstrom R, Lipworth L, Kramer MS. Prepregnancy weight and the risk of adverse pregnancy outcomes. N Engl J Med 1998;338:147-52.

9. Baeten JM, Bukusi EA, Lambe M. Pregnancy complications and outcomes among overweight and obese nulliparous women. Am J Public Health 2001;91:436-40.

10. Zhang Y, Proenca M, Maffei M, Barone M, Leopold L, Friedman JM. Positional cloning of the mouse obese gene and its human homologue. Nature 1994;372:425-32.

11. Campfield LA, Smith FJ, Guisez Y, Devos R, Burn P. Recombinant mouse $\mathrm{OB}$ protein: Evidence for a peripheral signal linking adiposity and central neural networks. Science 1995;269:546-9.

12. Halaas JL, Gajiwala KS, Maffei M, Cohen SL, Chait BT, Rabinowitz D, et al. Weight-reducing effects of the plasma protein encoded by the obese gene. Science 1995;269:543-6.

13. Maffei M, Halaas J, Ravussin E, Pratley RE, Lee GH, Zhang Y, et al. Leptin levels in human and rodent: Measurement of plasma leptin and ob RNA in obese and weight-reduced subjects. Nat Med 1995;1:1155-61.

14. Pelleymounter MA, Cullen MJ, Baker MB, Hecht R, Winters D, Boone T, et al. Effects of the obese gene product on body weight regulation in ob/ob mice. Science 1995;269:540-3.

15. Weigle DS, Bukowski TR, Foster DC, Holderman S, Kramer JM, Lasser $\mathrm{G}$, et al. Recombinant ob protein reduces feeding and body weight in the ob/ob mouse. J Clin Invest 1995 96:2065-70.

16. Mantzoros CS, Qu D, Frederich R, Susulic VS, Lowell BB, Maratos-Flier E, et al. Activation of beta (3) adrenergic receptors suppresses leptin expression and mediates a leptin-independent inhibition of food intake in mice. Diabetes 1996;45:909-14.

17. Ahima RS, Prabakaran D, Mantzoros C, Qu D, Lowell B, Maratos-Flier E, et al. Role of leptin in the neuroendocrine response to fasting. Nature 
1996;382:250-2.

18. Smith JT, Waddel BJ. Developmental changes in plasma leptin and hypothalamic leptin receptor expression in the rat: Peripubertal changes and the emergence of sex differences. J Endocrinol 2003;176:313-9.

19. Hassink SG, de Lancey E, Sheslow DV, Smith-Kirwin SM, O'Connor DM, Considine RV, et al. Placental leptin: An important new growth factor in intrauterine and neonatal development? Pediatrics 1997;100:E1.

20. Yamashita H, Shao J, Ishizuka T, Klepcyk PJ, Muhlenkamp P, Qiao L, et al. Leptin administration prevents spontaneous gestational diabetes in heterozygous Lepr $(\mathrm{db} /+)$ mice: Effects on placental leptin and fetal growth. Endocrinol 2001;142:2888-97.

21. Christou H, Connors JM, Ziotopoulou M, Hatzidakis V, Papathanassoglou E, Ringer SA, et al. Cord blood leptin and insulin-like growth factor levels are independent predictors of fetal growth. J Clin Endocrinol Metab 2001;86:935-8.

22. Prasad AS, Mantzoros CS, Beck FW, Hess JW, Brewer GJ. Zinc status and serum testosterone levels of healthy adults. Nutrition 1996;12:344-8.

23. McClain G, Stuart M, Kasarskis E, Humphries L. Zinc, appetite regulation and eating disorders. In: Prasad AS, editor. "Essential and Toxic Trace Elements in Human Health and Disease: An update". New York: Wiley-Liss Inc; 1993. p. 47-64.

24. Ozdemir U, Gulturk S, Aker A, Guvenal T, Imir G, Erselcan T. Correlation between birth weight, leptin, zinc and copper levels in maternal and cord blood. J Physiol Biochem 2007;63:121-8.

25. Silverstone T. Appetite suppressants: A review. Drugs 1992;43:820-36.

26. Mantzoros CS, Prasad AS, Beck FW, Grabowski S, Kaplan J, Adair C, et al. Zinc may regulate serum leptin concentrations in humans. J Am Coll Nutr 1998;17:270-5.

27. Mangian HF, Lig G, Paul GL, Shay NF. Blood leptin levels are reduced during zinc deficiency induced anorexia. FASEB 1997;11:A1124.

28. Hossain KJ, Kamal MM, Ahsan M, Islam SN. Serum antioxidant micromineral $(\mathrm{Cu}, \mathrm{Zn}, \mathrm{Fe})$ status of drug dependent subjects: Influence of illicit drugs and lifestyle. Subst Abuse Treat Prev Policy 2007;2:12.

29. Ashworth CJ, Antipatis C. Micronutrient programming of development throughout gestation. Reproduction 2001;122:527-35.

30. Blum WF, Englaro P, Hanitsch S, Juul A, Hertel NT, Muller J, et al. Plasma leptin levels in healthy children and adolescents: Dependence on body mass index, body fat mass, gender, pubertal stage and testosterone. J Clin Endocrinol Metab 1997;82:2904-10.

31. Nwagha UI, Nwachukwu D, Dim C, Ibekwe PC, Onyebuchi A. Maternal mortality trend in South East Nigeria: Less than a decade to the millennium developmental goals. J Womens Health (Larchmet) 2010;19:323-7.

32. State Ministry of Health, Enugu Health Sector Reform: Implementing the District Health System. Posted 2004. Available from: http://www. enugustate.gov.ng/[Last accessed on 2010 Aug 30].

33. Onah HE, Okaro JM, Umeh U, Chigbu CO. Maternal mortality in health institutions with emergency obstetric care facilities in Enugu State, Nigeria. J Obstet Gynaecol 2005;25:569-74.

34. Ezugwu EC, Onah HE, Ezugwu FO, Okafor II. Maternal mortality in a transitional hospital in Enugu, South East Nigeria. Afr J Reprod Health 2009;13:67-72.

35. Szreter SR. The Official representation of Social Classes in Britain, the United States and France: The Professional Model and "Les Cadres". Comp Stud Soc Hist 1993;2:285-317.
36. Oguntano EB, Akinyele IO. Nutrient Composition of commonly eaten foods in Nigeria; raw, processed and prepared. Ibadan, Nigeria: Food Basket foundation Publication series; 1995.

37. Paul AA, Southgate DA, Editor. The composition of foods. $4^{\text {th }}$ ed. London: Her Majesty Stationery Office (HMSO); 1979.

38. Prasad AS. Discovery of human zinc deficiency and studies in an experimental human model. Am J Clin Nutr 1991;53:403-12.

39. Halaas ES, Wallwork JS, Sandstead HH. Mild zinc deficiency and undernutrition during the prenatal and postnatal periods in rats: Effects on weight, food consumption and brain catecholamine concentrations. J Nutr 1982;112:542-51.

40. Essatara MB, Morley JE, Levine AS, Elson MK, Shafer RB, McLain CJ. The role of the endogenous opiates in zinc deficiency anorexia. Physiol Behav 1984;32:475-8.

41. Ott ES, Shay NF. Zinc deficiency reduces leptin gene expression and leptin secretion in rat adipocytes. Exp Biol Med (Maywood) 2001;226:841-6.

42. Torloni MR, Betran AP, Horta BL, Nakamura MU, Atallah AN, Moron AF, et al. Prepregnancy BMI and the risk of gestational diabetes: A systematic review of the literature with meta-analysis. Obes Rev 2009;10:194-203.

43. Vukelić J, Kapamadžija A, Petrović D, Grujić Z, Novakov-Mikić A, Kopitović $\mathrm{V}$, et al. Variations of serum copper values in pregnancy. Srp Arh Celok Lek 2012;140:42-6.

44. Izquierdo Alvarez S, Castañón SG, Ruata ML, Araguiés EF, Terraz PB, Irazabal YG, et al. Updating of normal levels of copper, zinc and selenium in serum of pregnant women. J Trace Elem Med Biol 2007;21:49-52.

45. Nwagha UI, Ogbodo SO, Nwogu-Ikojo EE, Ibegbu DM, Ejezie FE, Nwagha TU, et al. Copper and selenium status of healthy pregnant women in Enugu, southeastern Nigeria. Niger J Clin Pract 2011;14:408-12

46. Ugwuja El, Akubugwo EI, Ibiam UA, Obidoa O. Impact of maternal copper and zinc status on pregnancy outcomes in a population of pregnant Nigerians. Pak J Nutr 2010;9:678-82.

47. Ugwuja EI, Akubugwo EI, Ibiam U, Obodoa O, Ugwu NC. Plasma copper and zinc among pregnant women in Abakaliki, Southeastern Nigeria. Internet J Nutr Wellness 2010;10:1 .

48. Ogbodo S, Nwagha U, Okaka A, Okeke A, Chukwurah F, Ezeonu P. Low levels of some nutritional parameters of pregnant women in a rural community of South East Nigeria: Implications for the attainment of the millennium developmental goal. Ann Med Health Sci Res 2012;2:49-55.

49. Dreno B, Blouin E. Acne, pregnant women and zinc salts: A literature review. Ann Dermatol Venereol 2008;135:27-33.

50. Hambidge KM, Krebs NF, Jacobs MA, Favier A, Guyette L, Ikle DN. Zinc nutritional status during pregnancy: A longitudinal study. Am J Clin Nutr 1983;37:429-42.

51. Ejezie F, Nwagha U. Zinc concentration during pregnancy and lactation in Enugu, South-East Nigeria. Ann Med Health Sci Res 2011;1:69-76.

52. Chigbu C, Aja L. Obesity in pregnancy in Southeast Nigeria. Ann Med Health Sci Res 2011;1:135-40.

How to cite this article: Nwagha UI, lyare EE, Ogbodo SO, Agu PU, Olubobokun TH, Ezeonu PO, et al. Parity-related changes in body weight may influence the zinc and copper status of urban pregnant women: A report from south eastern Nigeria. J Basic Clin Reprod Sci 2013;2:32-7.

Source of Support: Nil, Conflict of Interest: None declared 